\title{
Pleural lavage with distilled water during surgery for esophageal squamous cell carcinoma
}

\author{
TOSHIYUKI KOSUGA $^{1 *}$, ATSUSHI SHIOZAKI ${ }^{1 *}$, DAISUKE ICHIKAWA ${ }^{1}$, \\ HITOSHI FUJIWARA ${ }^{1}$, SHUHEI KOMATSU ${ }^{1}$, DAISUKE IITAKA ${ }^{1}$, MASAHIRO TSUJIURA ${ }^{1}$, \\ RYO MORIMURA $^{1}$, HIROKI TAKESHITA ${ }^{1}$, HIROAKI NAGATA ${ }^{1}$, KAZUMA OKAMOTO ${ }^{1}$, \\ TAKASHI NAKAHARI ${ }^{3}$, YOSHINORI MARUNAKA ${ }^{2}$ and EIGO OTSUJI $^{1}$
}

${ }^{1}$ Division of Digestive Surgery, Department of Surgery, and ${ }^{2}$ Department of Molecular Cell Physiology, Kyoto Prefectural University of Medicine, Kyoto, 602-8566; ${ }^{3}$ Department of Physiology, Osaka Medical College, Takatsuki, 569-8686, Japan

Received March 15, 2011; Accepted April 27, 2011

DOI: $10.3892 /$ or.2011.1307

\begin{abstract}
This study aimed to investigate cytocidal effects of hypotonic shock on esophageal squamous cell carcinoma (ESCC) cell lines, and to apply pleural lavage with distilled water to surgery for ESCC. Three human ESCC cell lines, TE5, TE9 and KYSE170 were exposed to distilled water, and morphological changes in ESCC cells were closely observed under a differential interference contrast microscope connected to a high-speed digital video camera. Further, serial cell volume changes after hypotonic shock were measured using a high-resolution flow cytometer. To investigate the cytocidal effects of hypotonic shock on ESCC cells, re-incubation of ESCC cells was performed after hypotonic shock. Additionally, the effects of 5-nitro-2-(3-phenylpropylamino)-benzoic acid (NPPB), a $\mathrm{Cl}^{-}$channel blocker, during hypotonic shock were analyzed. Video recordings by high-speed digital camera demonstrated that hypotonic shock with distilled water induced cell swelling followed by cell rupture. Measurements of cell volume changes using a high-resolution flow cytometer indicated that severe hypotonicity with distilled water increased broken fragments of ESCC cells within 5 min. Re-incubation experiments demonstrated cytocidal effects of hypotonic shock on ESCC cells. Treatment of cells with NPPB increased cell volumes by the inhibition of regulatory volume decrease, which is observed during hypotonic shock, and enhanced cytocidal effects. These findings demonstrated the cytocidal effects of hypotonic shock on ESCC cells, and clearly support the efficacy of pleural lavage with distilled water during surgery for ESCC.
\end{abstract}

Correspondence to: Dr Atsushi Shiozaki, Division of Digestive Surgery, Department of Surgery, Kyoto Prefectural University of Medicine, 465 Kajii-cho, Kamigyo-ku, Kyoto 602-8566, Japan

E-mail: shiozaki@koto.kpu-m.ac.jp

*Contributed equally

Key words: esophageal cancer, surgery, irrigation, water

\section{Introduction}

The presence of exfoliated cancer cells in the pleural cavity after resection of thoracic esophageal carcinoma has been reported (1-4), and positive pleural lavage cytology before thoracic closure is recognized as a prognostic indicator of recurrence in thoracic esophageal carcinoma $(1,3)$. Therefore, effective pleural lavage is clinically important at the time of initial surgery of thoracic esophageal carcinoma because exfoliated cancer cells may be viable and tumorigenic. Although intraoperative pleural lavage with saline solution has been widely performed, it may be difficult to remove all of the exfoliated cancer cells from the pleural cavity. Accordingly, pleural lavage with distilled water has been performed during thoracic surgery for various cancers, but there is no systematic study elucidating its efficacy during surgery for thoracic esophageal carcinoma. Furthermore, there are no experimental data demonstrating the cytocidal effects of distilled water on esophageal squamous cell carcinoma (ESCC) cell lines due to hypotonic shock.

In the present study, we analyzed changes in cellular morphology and volume after hypotonic shock in detail, and determined the osmolarity and incubation time necessary to kill ESCC cells using several unique methods, such as a differential interference contrast (DIC) microscope connected to a high-speed digital video camera, a high-resolution flow cytometer and re-incubation experiment. Further, we treated ESCC cells with 5-nitro-2-(3-phenylpropylamino)-benzoic acid (NPPB), a $\mathrm{Cl}^{-}$channel blocker, to enhance cytocidal effects by increasing cell volumes during hypotonic shock via the inhibition of regulatory volume decrease (RVD) $(5,6)$. These findings clearly support the efficacy of pleural lavage with distilled water during surgery for ESCC.

\section{Materials and methods}

Cell culture and materials. The human ESCC cell lines, TE5 (poorly differentiated) and TE9 (poorly differentiated) were obtained from the Cell Resource Center for Biomedical Research Institute of Development, Aging and Cancer (Tohoku 
University, Sendai, Japan) (7). The human ESCC cell line KYSE170 (moderately differentiated) was obtained from Kyoto University (Kyoto, Japan) (8). These cells were grown on plastic culture flasks (Corning Incorporated, NY, USA) in RPMI-1640 medium (Nacalai Tesque, Kyoto, Japan) supplemented with $100 \mathrm{U} / \mathrm{ml}$ of penicillin and $100 \mu \mathrm{g} / \mathrm{ml}$ of streptomycin, and $10 \%$ fetal bovine serum (FBS). The flasks were kept in a humidified incubator at $37^{\circ} \mathrm{C}$ with $5.0 \% \mathrm{CO}_{2}$ in air. NPPB was purchased from BIOMOL International, L.P (Plymouth Meeting, PA).

Solutions and measurement of osmolality. The $140 \mathrm{mM}$ isotonic $\mathrm{NaCl}$ buffer contained $140 \mathrm{mM} \mathrm{NaCl}, 5.0 \mathrm{mM} \mathrm{KCl}$, $1.0 \mathrm{mM} \mathrm{CaCl}_{2}, 1.0 \mathrm{mM} \mathrm{MgCl}_{2}, 5.0 \mathrm{mM}$ glucose and $10 \mathrm{mM}$ HEPES. The osmolality of the solutions was measured using a freezing point osmometer (model 110, Fiske Associates, Norwood, MA) and was determined as $300 \pm 4.0$ [mean \pm standard error of the mean (SEM), $\mathrm{n}=5] \mathrm{mOsmol} / \mathrm{kgH}_{2} \mathrm{O}$ for the isotonic $\mathrm{NaCl}$ buffer. In order to analyze cell volume changes after hypotonic shock of various osmolalities, graded hypotonic $\mathrm{NaCl}$ buffers were produced by diluting 2-, 4- and 16 -fold with distilled water. Accordingly, the osmolality of each hypotonic $\mathrm{NaCl}$ buffer was determined as $148 \pm 4.4$, $90.0 \pm 4.6$ and $24.3 \pm 2.0$ (means $\pm \mathrm{SEM}, \mathrm{n}=3$ ) $\mathrm{mOsmol} / \mathrm{kgH}_{2} \mathrm{O}$, respectively. The osmolarity of distilled water was determined as $0 \mathrm{mOsmol} / \mathrm{kgH}_{2} \mathrm{O}(\mathrm{n}=3)$. All solutions used in the present study were adjusted to $\mathrm{pH}$ 7.40.

Observation of morphological changes in ESCC cells after exposure to distilled water. ESCC cells were detached from flasks in a trypsin-EDTA solution and centrifuged. Isotonic ( $300 \mathrm{mOsmol} / \mathrm{kgH}_{2} \mathrm{O}$ ) $\mathrm{NaCl}$ buffer was added to the pelleted cells and the suspended cells were mounted on a coverslip precoated with neutralized Cell-Tak (Becton-Dickinson Labware, Bedford, MA, USA) for firm attachment of the cells. The coverslip with the cells was set in a perfusion chamber that was mounted on the stage of a DIC microscope (BX50Wi, Olympus, Tokyo, Japan) connected to a video-enhanced contrast (VEC) system (ARGUS-20, Hamamatsu Photonics, Hamamatsu, Japan), and images were continuously recorded by a video recorder according to the procedure described previously (9). The experiments were performed at $37^{\circ} \mathrm{C}$. The volume of the perfusion chamber was approximately $20 \mu \mathrm{l}$ and the rate of perfusion was $200 \mu \mathrm{l} / \mathrm{min}$. At first, the isotonic $\mathrm{NaCl}$ buffer was perfused in the chamber. Then, this was changed to distilled water and serial changes in ESCC cells were observed.

Measurements of cell volume changes in ESCC cells after hypotonic shock. ESCC cells grown on culture flasks were detached from culture flasks in a trypsin-EDTA solution and centrifuged. Then, $7.5 \times 10^{6}$ cells in pellets were suspended in 1-ml distilled water or hypotonic $\mathrm{NaCl}$ buffer of various osmolalities to induce hypotonic shock. The suspending solution was displaced into a Vi-CELL ${ }^{\mathrm{TM}}$ Sample Cup (Beckman Coulter, Fullerton, CA) and the cell volume was measured 1, 5 and $10 \mathrm{~min}$ after induction of hypotonic shock using a high-resolution flow cytometer, Cell Lab Quanta (Beckman Coulter). This flow cytometer is designed to measure the electronic volume (EV) by the Coulter Principle and is more accurate than the volume detected by forward angle light scattering analysis by a conventional flow cytometer. All data on EV were analyzed by Quanta control software. EV of more than 10,000 cells was collected in each measurement. The cell suspension in the isotonic (300 mOsmol/ $\mathrm{kgH}_{2} \mathrm{O}$ ) $\mathrm{NaCl}$ buffer was used as a sample without hypotonic shock (0 min). For experiments with NPPB, cells were pre-incubated with NPPB for $30 \mathrm{~min}$ at $37^{\circ} \mathrm{C}$ with $5.0 \% \mathrm{CO}_{2}$ in air.

Re-incubation of ESCC cells after exposure to distilled water. ESCC cells grown on culture flasks were detached from culture flasks in a trypsin-EDTA solution and centrifuged. The cells were suspended in culture medium and $2.5 \times 10^{5}$ TE5 or TE9 cells, or $1.5 \times 10^{5}$ KYSE170 cells, respectively, were placed in each centrifuging tube. The cell suspension was centrifuged, and the pelleted cells were re-suspended in distilled water and incubated for 1, 5, 10, 20 or $30 \mathrm{~min}$. Thereafter, the suspension was centrifuged, and the cells in pellets were suspended in culture medium and seeded into Costar ${ }^{\circledR}$ 6-well plates (Corning Incorporated, NY, USA). At $48 \mathrm{~h}$ after plating, the cells were detached from the plates in a trypsin-EDTA solution and counted on a hemocytometer. The cell suspension in isotonic $\left(300 \mathrm{mOsmol} / \mathrm{kgH}_{2} \mathrm{O}\right) \mathrm{NaCl}$ buffer was used as a sample without hypotonic shock (0 min). For experiments with NPPB, cells were pre-incubated with NPPB for $30 \mathrm{~min}$ at $37^{\circ} \mathrm{C}$ with $5.0 \% \mathrm{CO}_{2}$ in air.

Pleural lavage fluid during surgery. Pleural lavage with distilled water was performed in 5 patients during surgery for ESCC. Before thoracic closure, $1,000 \mathrm{ml}$ of distilled water was poured into pleural cavity and left for $5 \mathrm{~min}$ with agitation. Thereafter, lavage fluid was collected and the osmolarity was measured using a freezing point osmometer.

Statistical analysis. Results were expressed as means \pm SEM. Statistical analyses were carried out using Student's t-test. Differences were considered significant when the P-value was $<0.05$.

\section{Results}

Changes of individual ESCC cells after exposure to distilled water. We observed the morphological changes in ESCC cells after exposure to distilled water using a DIC microscope connected to a VEC system. ESCC cells started swelling as soon as the cells were exposed to distilled water, and then continued swelling followed by rupture. These changes were observed in each of the three ESCC cell lines (Fig. 1). Rupture of ESCC cells occurred within 3 min after perfusion of distilled water.

Cell volume changes of ESCC cells after hypotonic shock. To quantify serial cell volume changes in ESCC cells after hypotonic shock of various osmolarities, we measured the cell volume and cell counts simultaneously after hypotonic shock using Cell Lab Quanta. Fig. 2 shows the results of simultaneous measurements of cell volume and cell counts of TE5 (Fig. 2A), TE9 (Fig. 2B) or KYSE170 cells (Fig. 2C) before and after hypotonic shock of various osmolarities. Once ESCC cells 


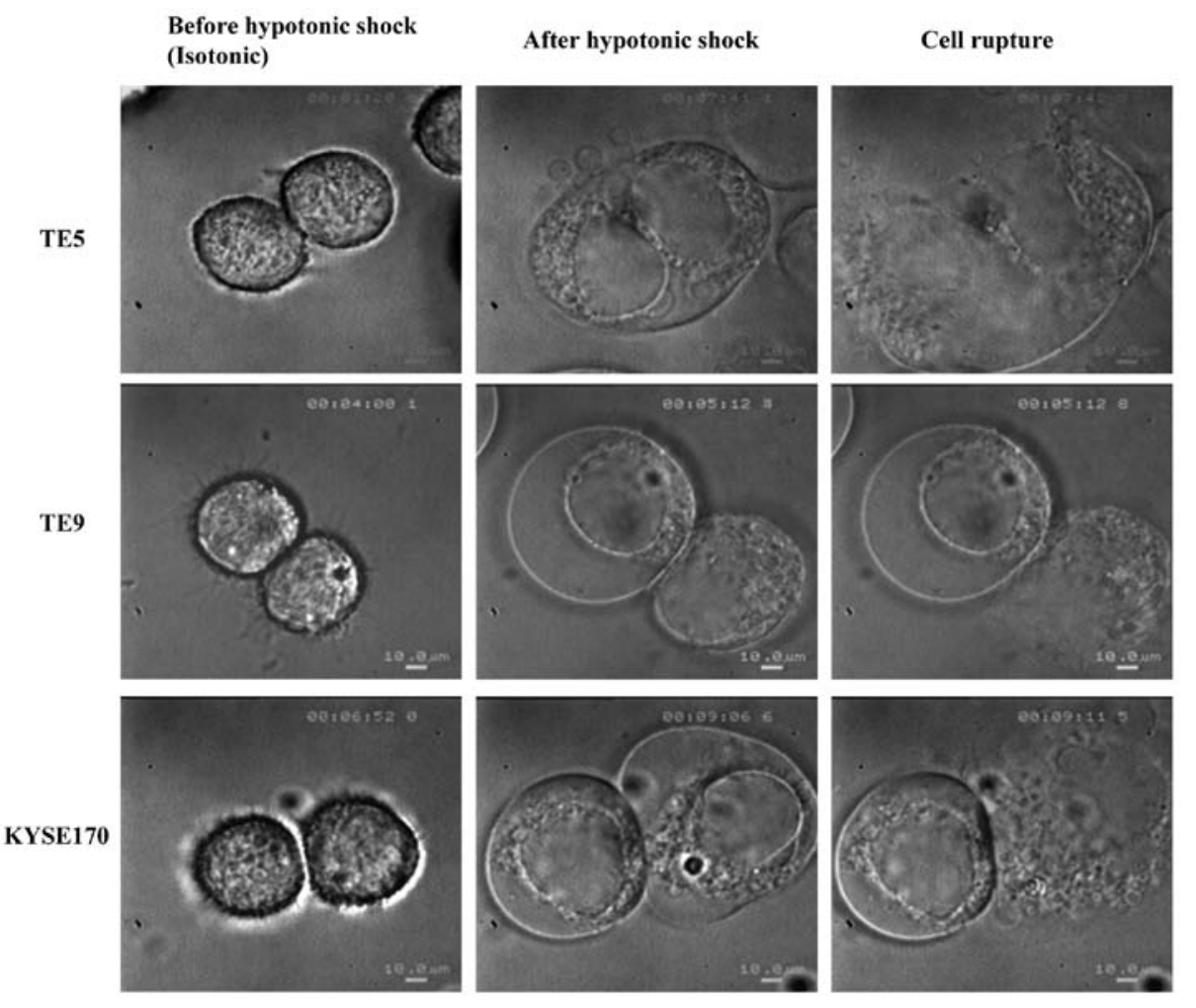

Figure 1. Changes in individual ESCC cells after hypotonic shock with distilled water. Representative images of TE5, TE9 and KYSE170 cells before and after hypotonic shock with distilled water are shown. ESCC cells continued to swell followed by cell rupture after hypotonic shock with distilled water.

were suspended in the hypotonic buffers, the cells initially increased in cell volume. Severe cell swelling was observed depending on low osmolarity. When the cells were exposed to mild hypotonicity (90-148 $\mathrm{mOsmol} / \mathrm{kgH}_{2} \mathrm{O}$ ), the cell volume decreased gradually to their pre-hypotonic shock level, maintaining a monomodal distribution despite the continued presence of extracellular hypotonicity. For example, the temporal changes of mean cell volume (MCV) of TE5, TE9 and KYSE170 cells 0, 1, 3, 5, 10 and 20 min after hypotonic shock of $148 \mathrm{mOsmol} / \mathrm{kgH}_{2} \mathrm{O}$ were shown in Fig. 3, suggesting mild hypotonicity could induce RVD in ESCC cells. However, when the cells were exposed to even lower osmolarity ( $24 \mathrm{mOsmol} / \mathrm{kgH}_{2} \mathrm{O}$ ), the cell volume showed bimodal distribution. Although one peak of the cell volume was larger than that of their pre-hypotonic shock volume, the other peak was smaller than that of their pre-hypotonic shock volume. Moreover, when the cells were exposed to distilled water $\left(0 \mathrm{mOsmol} / \mathrm{kgH}_{2} \mathrm{O}\right)$, the overall cell volume was smaller than that of the pre-hypotonic shock volume, suggesting that almost all of the cells had broken into fragments (Fig. 4). These findings demonstrated that hypotonic shock with distilled water induced disruption of ESCC cells within 5 min. Additionally, we found differences in the cell volume changes by hypotonic shock among TE5, TE9 and KYSE170 cells. Although the cell volume $1 \mathrm{~min}$ after hypotonic shock with distilled water showed bimodal distribution in TE5 and TE9 cells, that in KYSE170 showed monomodal distribution. In TE5 or TE9 cells, the overall cell volume became smaller than the pre-hypotonic one, and the larger one of the two peaks disappeared within 5 min. However, in KYSE170 cells, it took $20 \mathrm{~min}$ for the larger peak of the cell volume to completely disappear after hypotonic shock with distilled water (data not shown), suggesting a difference in resistance to hypotonic shock.

Cytocidal effects of distilled water on ESCC cells. To confirm the cytocidal effects of hypotonic shock with distilled water on ESCC cells, re-incubation of ESCC cells was performed after exposure to distilled water. The decrease in the number of ESCC cells was depended on the duration of exposure to distilled water in each of the three ESCC cell lines (Fig. 5). We also found differences in cytocidal effects of hypotonic shock with distilled water among TE5, TE9 and KYSE170 cells. There were no surviving cells $48 \mathrm{~h}$ after 10 -min exposure to distilled water in TE5 and TE9 cell lines. However, KYSE170 cells were more resistant to cytocidal effects of hypotonic shock, and 30-min exposure to distilled water was needed for $1.5 \times 10^{5}$ cells to be killed completely. These findings were consistent with the results of cell volume changes after hypotonic shock, which were more remarkable in TE5 and TE9 cell lines.

Osmolarity of pleural lavage fluid during surgery. It is expected that distilled water poured into pleural cavity may be contaminated by existing intrapleural secretions and many types of cells in the pleural cavity. To demonstrate this, pleural lavage with distilled water was performed in 5 patients during surgery for ESCC. The measured osmolarity of collected fluid in 5 patients is shown in Table $\mathrm{I}$, and determined as 7.6 \pm 1.0 (mean $\pm \mathrm{SEM}$ ) $\mathrm{mOsmol} / \mathrm{kgH}_{2} \mathrm{O}$. Although the osmolality of collected fluid was not $0 \mathrm{mOsmol} / \mathrm{kgH}_{2} \mathrm{O}$, the elevation was found to be $<10 \mathrm{mOsmol} / \mathrm{kgH}_{2} \mathrm{O}$. 


\section{A TE5}

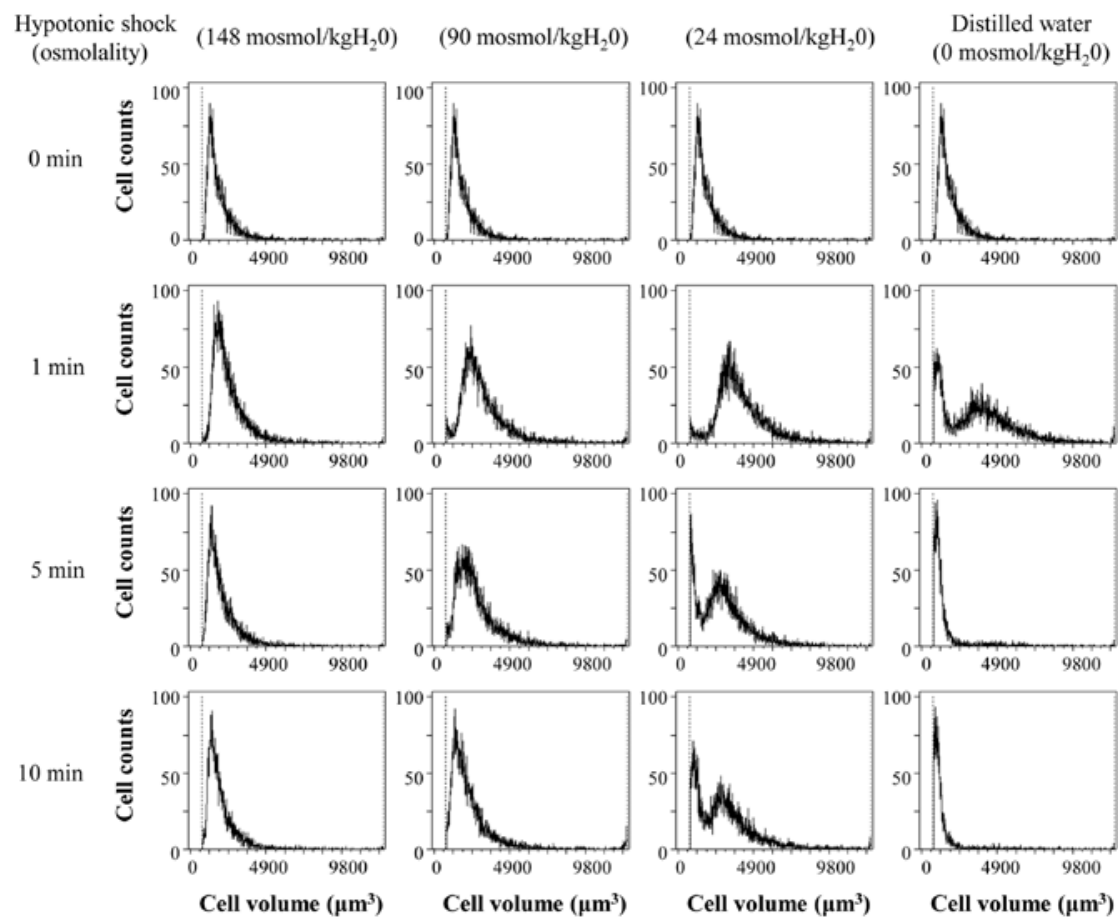

\section{B TE9}
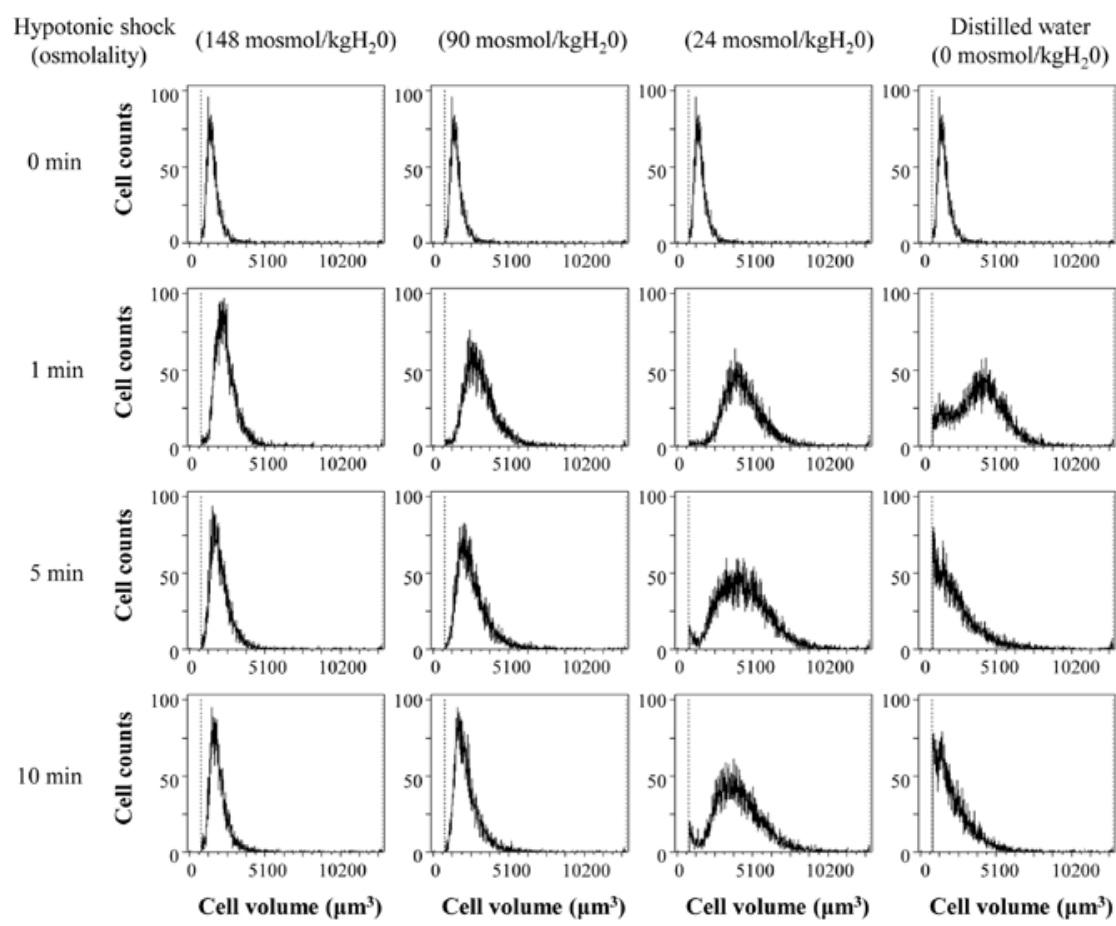

Figure 2A and B. Cell volume changes in TE5 (A) and TE9 (B) ESCC cells after hypotonic shock.

Difference in osmolarity between the solutions with and without suspended cells. It was expected that the osmolarity of each hypotonic solution with suspended cells would be higher than that without suspended cells as a result of the increase of osmolytes arising from the rupture of ESCC cells. To demonstrate this, the osmolarity of each solution with or without suspended TE5 cells was measured, and there was not a marked difference between two groups (Table II). Although the osmolarity of distilled water with suspended cells was around $10 \mathrm{mOsmol} / \mathrm{kgH}_{2} \mathrm{O}$ higher than that without suspended cells, this level was higher than the actual osmolarity of pleural lavage fluid during surgery. 


\section{KYSE170}

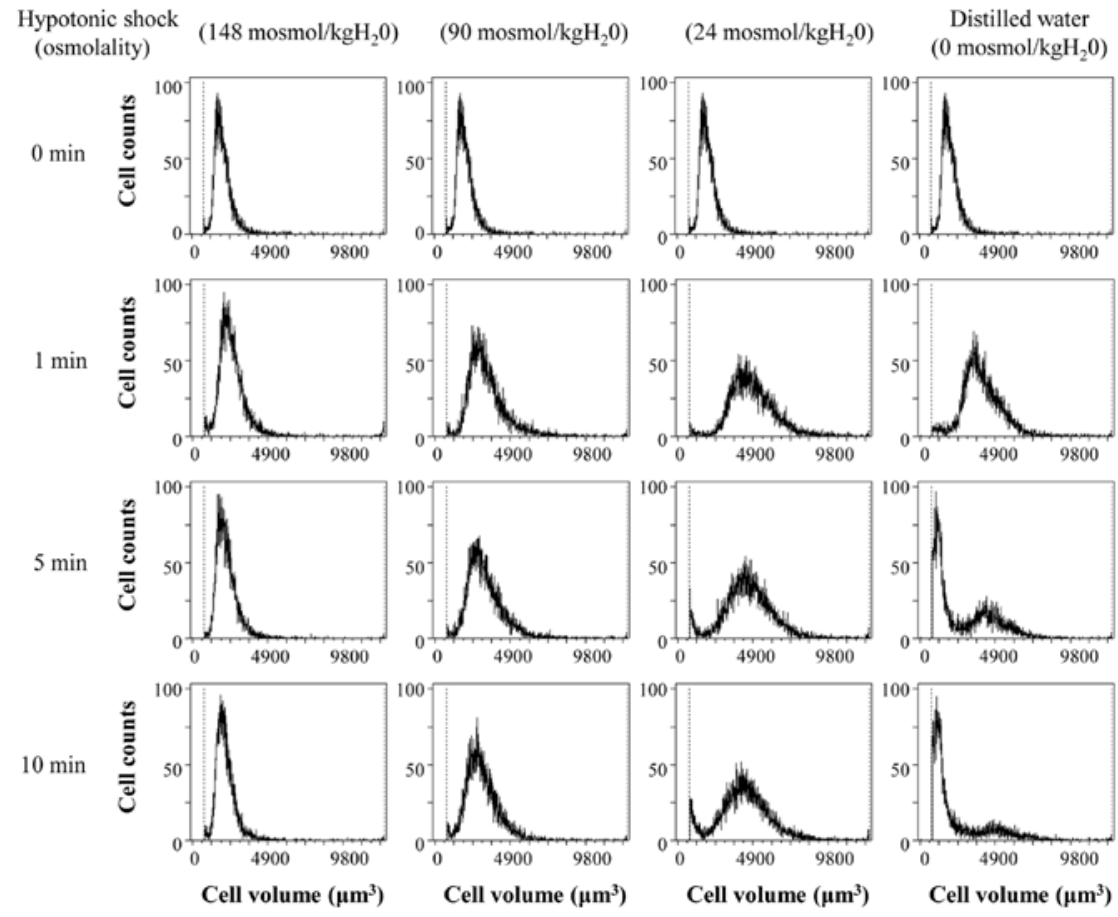

Figure 2C. Cell volume changes in ESCC cells after hypotonic shock. The cell volume and the cell counts of TE5 (A), TE9 (B) and KYSE170 cells (C) were simultaneously measured at 1, 5 and 10 min after hypotonic shock of various osmolarities using a high-resolution flow cytometer, Cell Lab Quanta. The isotonic $\left(300 \mathrm{mOsmol} / \mathrm{kgH}_{2} \mathrm{O}\right) \mathrm{NaCl}$ buffer was diluted 2-, 4-and 16-fold with distilled water, and the osmolarity of each hypotonic $\mathrm{NaCl}$ buffer is described in the figure. The cell suspension in the isotonic $\left(300 \mathrm{mOsmol} / \mathrm{kgH}_{2} \mathrm{O}\right) \mathrm{NaCl}$ buffer was used as a sample without hypotonic shock $(0 \mathrm{~min})$. When the cells were exposed to mild hypotonicity $\left(90-148 \mathrm{mOsmol} / \mathrm{kgH}_{2} \mathrm{O}\right)$, the cell volume initially increased and then decreased gradually to the pre-hypotonic shock level, maintaining a monomodal distribution despite the continued presence of the extracellular hypotonicity. When the cells were exposed to even lower osmolarity $\left(24 \mathrm{mOsmol} / \mathrm{kgH}_{2} \mathrm{O}\right)$, the cell volume showed a bimodal distribution. When the cells were exposed to distilled water $\left(0 \mathrm{mOsmol} / \mathrm{kgH}_{2} \mathrm{O}\right)$, the overall cell volume was smaller than the pre-hypotonic shock volume, suggesting that almost all of the cells had broken into fragments.

TE5

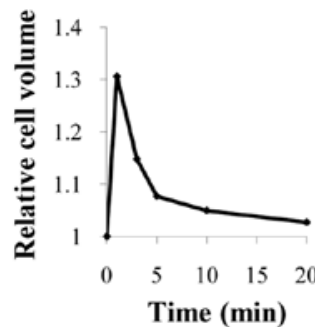

TE9

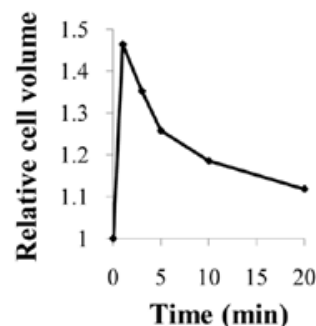

KYSE170

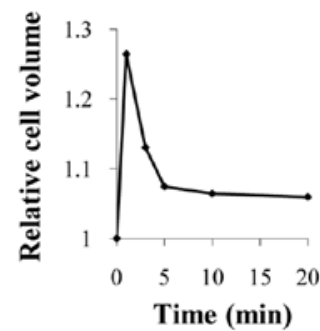

Figure 3. Cell volume changes in ESCC cells after mild hypotonic shock. Mean cell volumes (MCV) of TE5, TE9 and KYSE170 cells 1, 3, 5, 10 and 20 min after hypotonic shock of $148 \mathrm{mOsmol} / \mathrm{kgH}_{2} \mathrm{O}$ were presented as values relative to those at $0 \mathrm{~min}$. The cell suspension in isotonic $\left(300 \mathrm{mOsmol} / \mathrm{kgH}_{2} \mathrm{O}\right) \mathrm{NaCl}$ buffer was used as a sample without hypotonic shock ( 0 min). Mild hypotonicity caused a biphasic change in cell volume; i.e., initial cell swelling followed by regulatory volume decrease (RVD) returning the cell volume toward the original level.

NPPB, a Cl channel blocker, enhances swelling of ESCC cells by hypotonic shock. To investigate whether NPPB, a $\mathrm{Cl}^{-}$ channel blocker, effects on the cell volume changes of ESCC cells after hypotonic shock, the cell volume was measured at $1,5,10,20$ and $30 \mathrm{~min}$ after exposure to the hypotonic (90 mOsmol/ $\mathrm{kgH}_{2} \mathrm{O}$ ) $\mathrm{NaCl}$ buffer containing $200 \mu \mathrm{M}$ NPPB or $0.2 \%$ DMSO by using Cell Lab Quanta. The serial changes in MCV of TE5, TE9 and KYSE170 cells after exposure to hypotonic solutions with NPPB or DMSO are shown in Fig. 6A. NPPB enhanced swelling of ESCC cells during hypotonic shock. Furthermore, NPPB drastically slowed down the decrease in cell volume following cell swelling by hypo-tonic shock, suggesting that these effects were induced by the inhibition of RVD $(5,6)$. Therefore, ESCC cells treated with NPPB were forced to maintain an extremely large cell volume for a longer time than those treated with DMSO. The cell volume measured $10 \mathrm{~min}$ after exposure to the hypotonic (90 mOsmol $/ \mathrm{kgH}_{2} \mathrm{O}$ ) $\mathrm{NaCl}$ buffer containing $100 \mu \mathrm{M}$ NPPB, $200 \mu \mathrm{M}$ NPPB or $0.1 \%$ DMSO is represented as a value relative to that at $0 \mathrm{~min}$ in Fig. $6 \mathrm{~B}$. We found that NPPB 


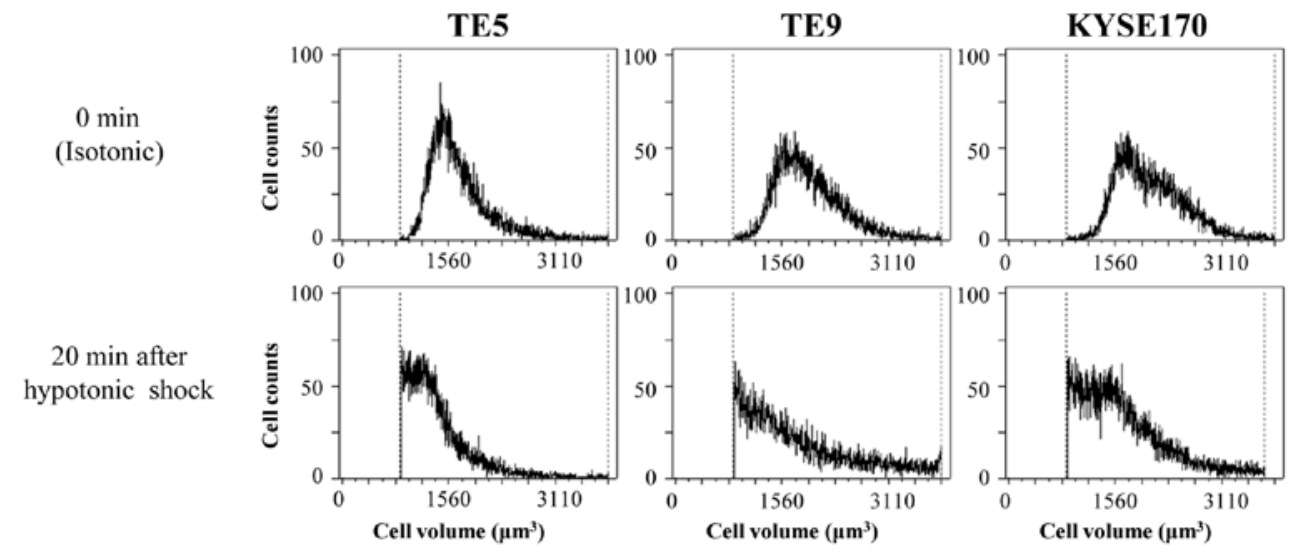

Figure 4. Cell volume of ESCC cells 20 min after hypotonic shock with distilled water. The cell volume and cell counts of TE5, TE9 or KYSE170 cells 20 min after hypotonic shock with distilled water were simultaneously measured by Cell Lab Quanta. The cell suspension in isotonic $\left(300 \mathrm{mOsmol} / \mathrm{kgH}_{2} \mathrm{O}\right) \mathrm{NaCl}$ buffer was used as a sample without hypotonic shock $(0 \mathrm{~min})$. In the figure, the small area of the cell volume was emphasized. The overall cell volume 20 min after hypotonic shock was smaller than that obtained at 0 min, suggesting that the cells were broken into fragments by hypotonic shock.

A

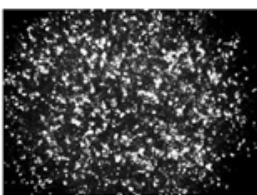

TE5

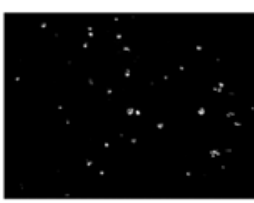

$5 \min$

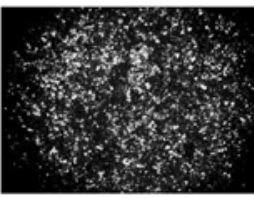

TE9

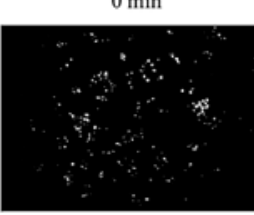

$5 \mathrm{~min}$

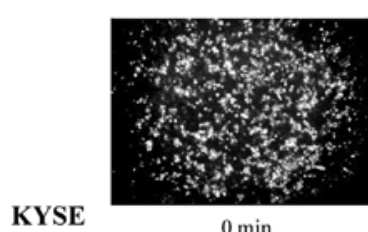

KYSE

$0 \mathrm{~min}$

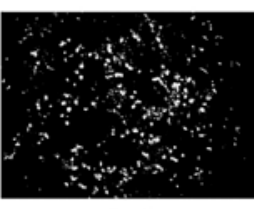

$5 \min$

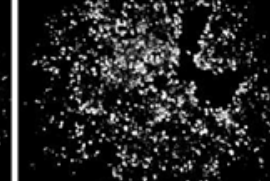

$1 \mathrm{~min}$

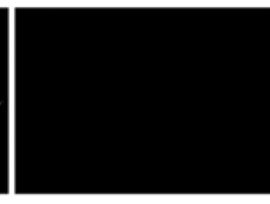

$10 \min$

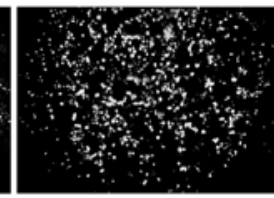

$1 \mathrm{~min}$

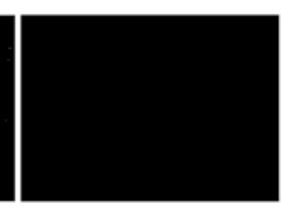

$10 \mathrm{~min}$

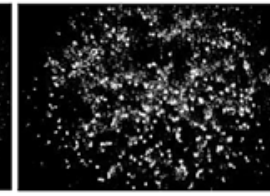

$1 \mathrm{~min}$

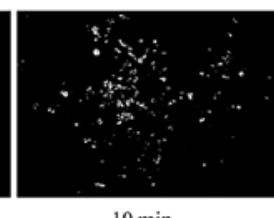

B

TE5

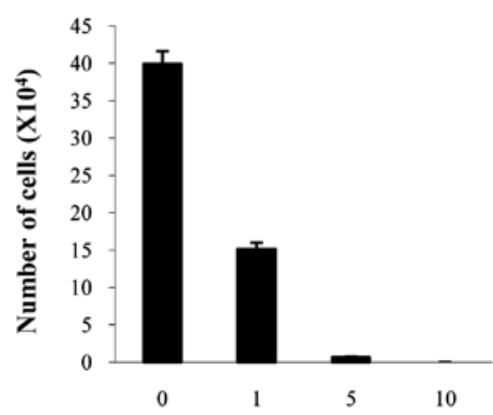

Exposed time (min)

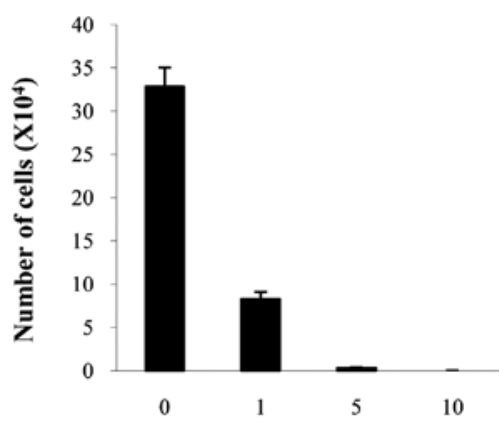

Exposed time (min)

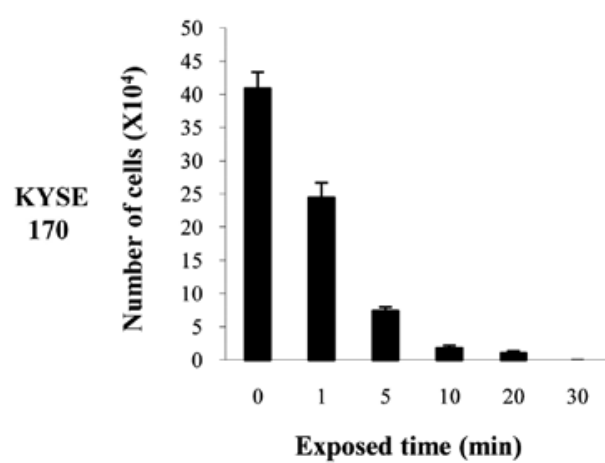

Figure 5. Re-incubation of ESCC cells after exposure to distilled water. (A) Representative pictures of cultured cells 48 h after 1-, 5- and 10-min exposure to distilled water. The cells exposed to isotonic (300 mOsmol/ $\left.\mathrm{kgH}_{2} \mathrm{O}\right) \mathrm{NaCl}$ buffer were used as a sample without hypotonic shock (0 min). (B) Cell numbers were counted $48 \mathrm{~h}$ after exposure to distilled water. The decrease in the number of surviving ESCC cells was dependent on the duration of exposure to distilled water in all three ESCC cell lines. Cytocidal effects induced by hypotonic shock with distilled water differed among TE5, TE9 and KYSE170 cells. The results are presented as the mean \pm SEM $(n=8)$. 
A
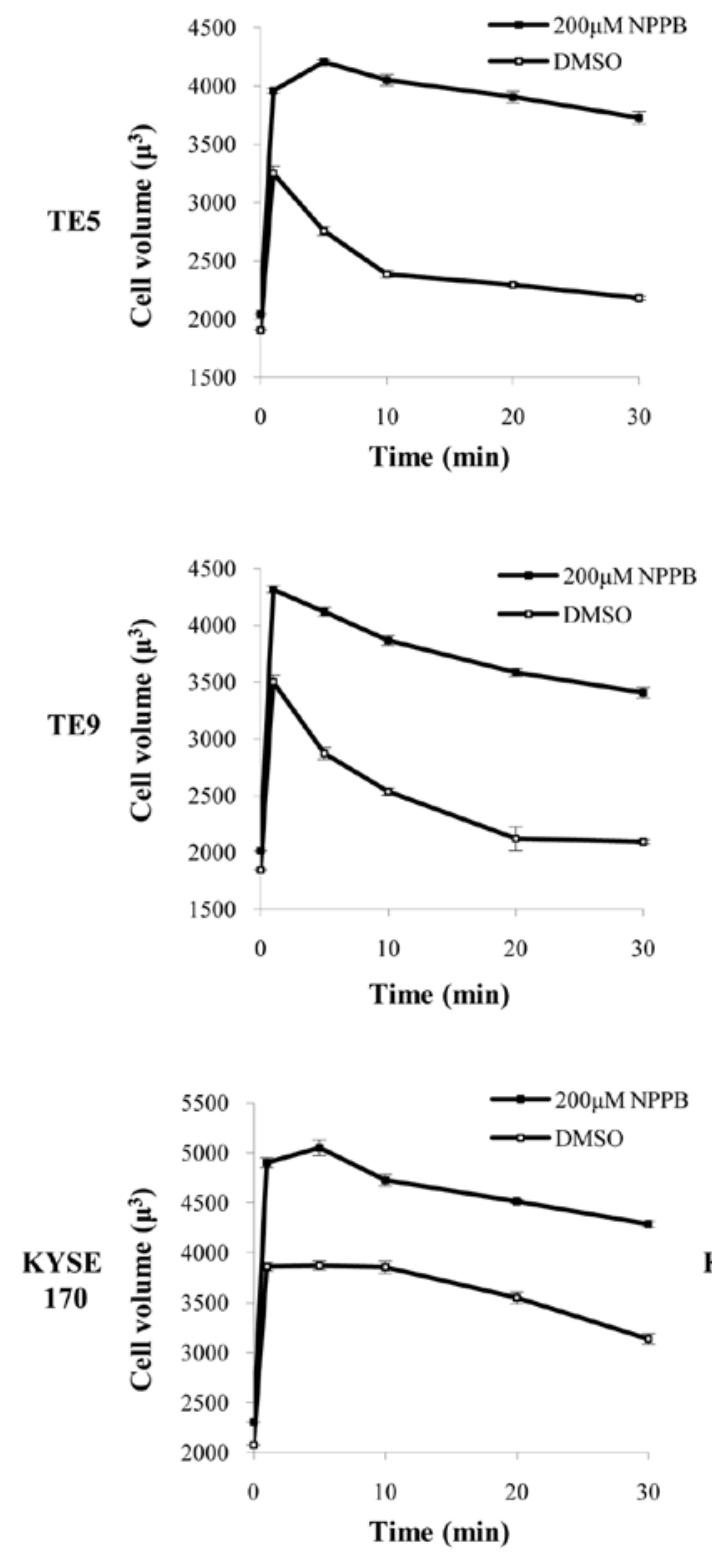

B

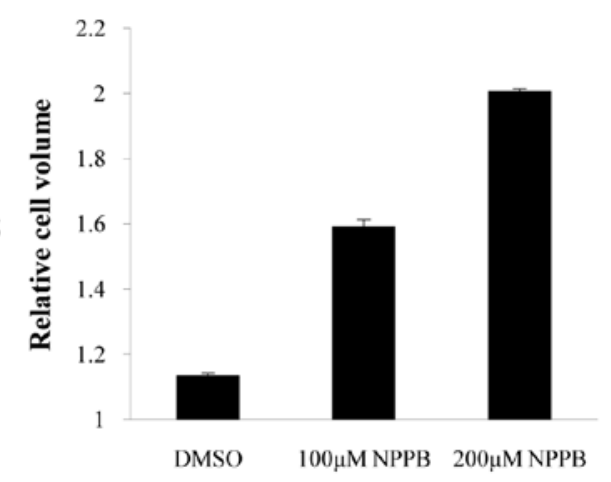

TE9
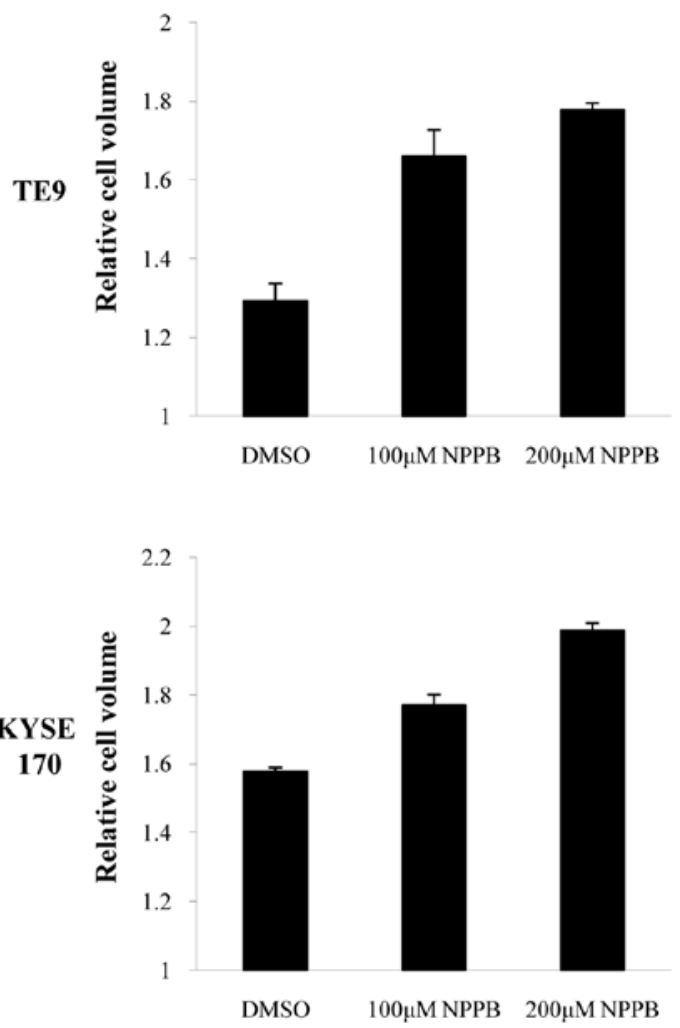

Figure 6. Effects of NPPB on hypotonicity-induced cell volume changes in ESCC cells. (A) The cell volume was measured 1, 5, 10, 20 and 30 min after exposure to hypotonic $\left(90 \mathrm{mOsmol} / \mathrm{kgH}_{2} \mathrm{O}\right) \mathrm{NaCl}$ buffer containing $200 \mu \mathrm{M} \mathrm{NPPB}$ or $0.2 \%$ DMSO. The cell suspension in isotonic $\left(300 \mathrm{mOsmol} / \mathrm{kgH}_{2} \mathrm{O}\right)$ $\mathrm{NaCl}$ buffer containing NPPB or DMSO was used as a sample without hypotonic shock $(0 \mathrm{~min})$. NPPB enhanced swelling of ESCC cells by hypotonic shock and drastically slowed down the decrease in cell volume after swelling. Each point shows the mean \pm SEM $(n=4)$. (B) The cell volume measured 10 min after exposure to hypotonic $\left(90 \mathrm{mOsmol} / \mathrm{kgH}_{2} \mathrm{O}\right.$ ) NaCl buffer containing $100 \mu \mathrm{M} \mathrm{NPPB}, 200 \mu \mathrm{M} \mathrm{NPPB}$ or $0.1 \%$ DMSO is represented as a value relative to that at 0 min. NPPB enhanced swelling of ESCC cells by hypotonic shock in a dose-dependent manner. The results are presented as the mean \pm SEM ( $\mathrm{n}=4$ ).

Table I. Osmolarity of pleural lavage fluid during surgery for ESCC.

Osmolarity $\left(\mathrm{mOsmol} / \mathrm{kgH}_{2} \mathrm{O}\right)$

\section{Case 1}

Case 2

Case 3

Case 4

Case 5

Mean \pm SEM $(n=5)$

\section{9}

8

4

7

10

$7.6 \pm 1.0$ enhanced swelling of ESCC cells during hypotonic shock in a dose-dependent manner. The effect of NPPB on cell volume was more remarkable in TE5 and TE9 cells than in KYSE170 cells.

$N P P B$ enhances cytocidal effects of hypotonic shock on ESCC cells. To investigate whether NPPB enhances cytocidal effects of hypotonic shock on ESCC cells, re-incubation of ESCC cells was performed after exposure to the hypotonic solution containing NPPB. Fig. 7 showed the number of surviving cells counted $48 \mathrm{~h}$ after 10 -min exposure to the hypotonic $\left(90 \mathrm{mOsmol} / \mathrm{kgH}_{2} \mathrm{O}\right) \mathrm{NaCl}$ buffer containing 
Table II. Osmolarity of the solutions with or without suspended TE5 cells.

\begin{tabular}{lcc}
\hline Dilution $^{\mathrm{a}}$ & ${\text { Before cell suspension }\left(\mathrm{mosmol} / \mathrm{kgH}_{2} \mathrm{O}\right)}^{\text {After cell suspension }\left(\mathrm{mosmol} / \mathrm{kgH}_{2} \mathrm{O}\right)}$ \\
\hline X1 (Isotonic NaCl buffer) & $300 \pm 4.0$ & $299 \pm 6.0$ \\
X2 & $148 \pm 4.4$ & $152 \pm 2.9$ \\
X4 & $90.0 \pm 4.6$ & $78 \pm 2.2$ \\
X16 & $24.3 \pm 2.0$ & $17 \pm 0.3$ \\
X0 (Distilled water) & 0 & $10 \pm 6.5$ \\
\hline
\end{tabular}

The results are presented as the means \pm SEM. The isotonic $\mathrm{NaCl}$ buffer before cell suspension, $\mathrm{n}=5$; the other solutions, $\mathrm{n}=3$. ${ }^{\mathrm{a}} \mathrm{The}$ isotonic $\mathrm{NaCl}$ buffer was diluted 2-, 4- and 16-fold with distilled water.

A

TE5

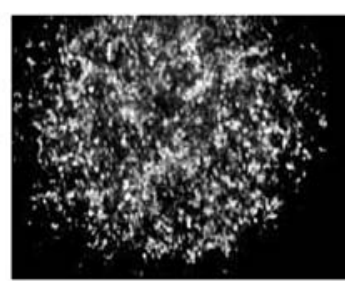

DMSO

TE9

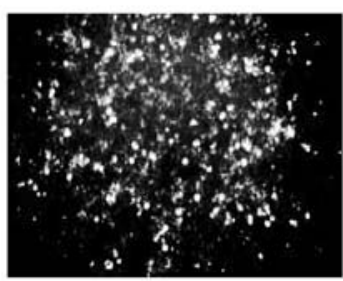

DMSO

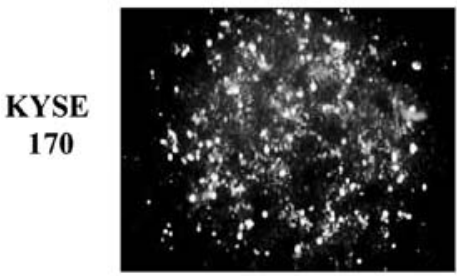

DMSO

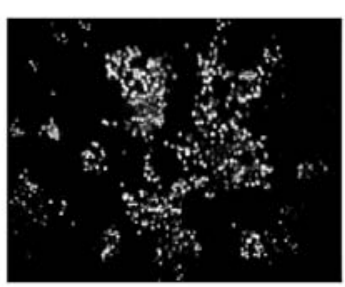

NPPB

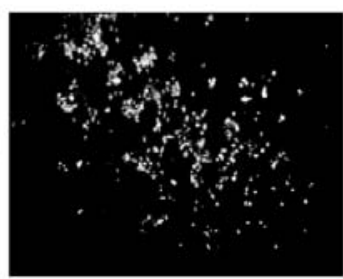

NPPB

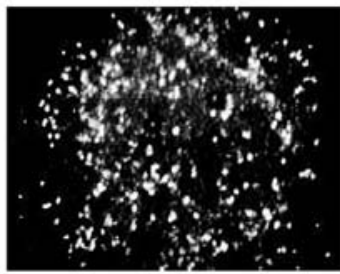

NPPB
B

TE5

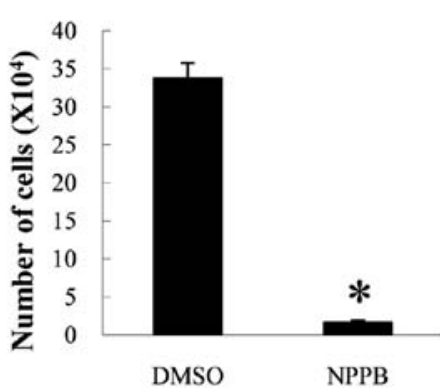

TE9
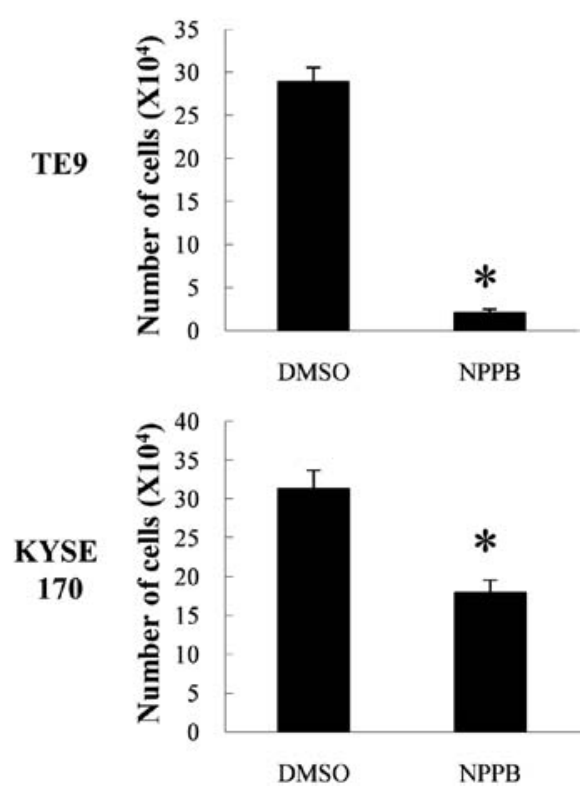

Figure 7. Re-incubation of ESCC cells after exposure to hypotonic solution containing NPPB. (A) Representative pictures of cultured cells $48 \mathrm{~h}$ after 10 -min exposure to hypotonic $\left(90 \mathrm{mOsmol} / \mathrm{kgH}_{2} \mathrm{O}\right) \mathrm{NaCl}$ buffer containing $200 \mu \mathrm{M} \mathrm{NPPB}$ or $0.2 \%$ DMSO. (B) Cell numbers were counted $48 \mathrm{~h}$ after 10 -min exposure to hypotonic $\left(90 \mathrm{mOsmol} / \mathrm{kgH}_{2} \mathrm{O}\right) \mathrm{NaCl}$ buffer containing $200 \mu \mathrm{M} \mathrm{NPPB}$ or $0.2 \%$ DMSO. NPPB enhanced cytocidal effects of hypotonic shock on ESCC cells. However, KYSE170 cells were more resistant to hypotonicity-induced cytocidal effects enhanced by NPPB than TE5 and TE9 cells. The results are presented as the mean \pm SEM $(n=12)$. $" p<0.05$ (DMSO vs. NPPB).

$200 \mu \mathrm{M}$ NPPB or $0.2 \%$ DMSO. We found that NPPB enhanced the cytocidal effects of hypotonic shock on all three ESCC cell lines. In this experiment, we also found differences in enhanced cytocidal effects of hypotonic shock with NPPB among TE5, TE9 and KYSE170 cells. These findings were consistent with the results showing cell swelling induced by NPPB, suggesting that cell volume regulation was the main mechanism underlying its cytocidal effects.

\section{Discussion}

Esophageal carcinoma is one of the main causes of cancerrelated death in the world (10). In Asian countries, the predominant histological type of esophageal carcinoma is squamous cell carcinoma, and tumors are frequently located in the thoracic esophagus. As in lung cancer (11-14), the presence of exfoliated cancer cells in the pleural cavity after 
resection of thoracic ESCC has been reported, and positive pleural lavage cytology has been recognized as a prognostic indicator of recurrence $(1,3)$. However, esophageal carcinomas are less likely to spontaneously exfoliate into the pleural cavity because most of the thoracic esophagus is not covered directly by the pleura but by adventitia. Therefore, it is suggested that surgical manipulation only occasionally exfoliates and spreads cancer cells in the surgical field. Some previous studies have indicated cytocidal effects of hypotonic shock on cancer cells (15-17). A previous report demonstrated the cytocidal activity of distilled water on colorectal cancer cell lines in culture, and also discussed the optimal method of peritoneal lavage with distilled water during colorectal cancer surgery (15). However, there is no underlying data demonstrating the cytocidal efficacy on ESCC cell lines and hence consensus on the optimal method of pleural lavage during surgery for ESCC is lacking.

As a basic point, we first confirmed that hypotonic shock with distilled water actually has cytocidal effects on individual ESCC cells using a DIC microscope connected to a highspeed digital video camera. Hypotonic shock with distilled water caused cell swelling followed by rupture of ESCC cells. Although the rupture of ESCC cells was observed within $3 \mathrm{~min}$ after perfusion of distilled water in the present experiments, it occurred where the extracellular osmolality might remain at nearly $0 \mathrm{mOsmol} / \mathrm{kgH}_{2} \mathrm{O}$ by continuous perfusion of distilled water in the chamber, and hence the changes in ESCC cells in a closed space such as in the pleural cavity were unclear. In addition, this study investigated the effects on only a small number of cells. Therefore, we subsequently investigated the changes in a large number of ESCC cells induced by hypotonic shock in a closed space.

It is very important to understand cell volume changes in ESCC cells after hypotonic shock of various osmolarities and elucidate how much hypotonic shock is needed for ESCC cells to be killed when we consider the mechanism involved in cytocidal effects by hypotonic shock. We quantified serial cell volume changes of ESCC cells after hypotonic shock of various osmolarities using a high-resolution flow cytometer, Cell Lab Quanta. When the cells were exposed to mild hypotonicity, the cell volume initially increased and subsequently decreased gradually to the pre-hypotonic shock level maintaining a monomodal distribution despite the continued presence of extracellular hypotonicity. Thus, mild hypotonicity could not break ESCC cells into fragments. With respect to these changes, many previous studies reported that hypotonicity caused a biphagic change in the cell volume; i.e., initial cell swelling followed by RVD returning the cell volume toward the original level. Although RVD was reported in many types of cells $(5,6,18-22)$, the present study is the first to report RVD in ESCC cell lines. We found that extremely severe hypotonicity was needed for ESCC cells to be broken into fragments, and demonstrated that distilled water was the most effective.

A previous report found that water used for peritoneal lavage was contaminated by secretions in the peritoneal cavity, but the degree of contamination was reduced after sequential lavage (15). In the present study, distilled water poured into the pleural cavity during surgery became contaminated and the osmolarity of collected fluid after lavage was not $0 \mathrm{mOsmol} / \mathrm{kgH}_{2} \mathrm{O}$, but the elevation was only $7.6 \pm 1.0$ (mean $\pm \mathrm{SEM}$ ) $\mathrm{mOsmol} / \mathrm{kgH}_{2} \mathrm{O}$. However, we also found that the elevation in the osmolarity was $10 \pm 6.5$ (mean \pm SEM) $\mathrm{mOsmol} / \mathrm{kgH}_{2} \mathrm{O}$ as the result of rupture of $7.5 \times 10^{6}$ TE5 cells exposed to $1-\mathrm{ml}$ distilled water. Therefore, the osmolarity of the solution before lavage has a more important influence on cytocidal effects than that after lavage.

We confirmed that hypotonic shock with distilled water actually has cytocidal effects on ESCC cells by re-incubation of ESCC cells after exposure to distilled water. Although 1-min exposure to distilled water reduced the surviving cell numbers to a certain extent, it took $10 \mathrm{~min}$ for $2.5 \times 10^{5} \mathrm{TE} 5$ or TE9 cells, or $30 \mathrm{~min}$ for $1.5 \times 10^{5} \mathrm{KYSE} 170$ cells to be killed completely. However, given the actual situation of surgery for thoracic esophageal carcinoma, it is unrealistic to perform pleural lavage for $30 \mathrm{~min}$ before thoracic closure. A previous report found that abdominal lavage with $0.9 \%$ saline more significantly reduced the numbers of cells during the first to third lavage cycle (23). Sequential lavage with distilled water for 10 min may be an appropriate method as long as significant proportions of ESCC cells are removed and killed because our study examined a much greater number of ESCC cells than the practical number of exfoliated cells likely to exist in the pleural cavity. However, it can not be denied that the elevation of the osmolality deteriorated the cytocidal effects on ESCC cells by distilled water. In the sense, sequential lavage may also be effective in that the osmolality of lavage fluid would be closer to $0 \mathrm{mOsmol} / \mathrm{kgH}_{2} \mathrm{O}$ with each lavage.

Consideration these problems, we added NPPB, a $\mathrm{Cl}^{-}$ channel blocker, to the hypotonic $\left(90 \mathrm{mOsmol} / \mathrm{kgH}_{2} \mathrm{O}\right)$ solution to enhance the cytocidal effects on ESCC cells. The efficiency of RVD depends on many factors. The involvement of $\mathrm{K}^{+}$and $\mathrm{Cl}^{-}$channels $(5,6,19,21)$ as well as stretch-activated channels (SACs) $(18,22)$ in RVD is well documented. Previous reports demonstrated that NPPB inhibit RVD as much as in other cell types $(5,6)$. In our study, we inhibited $\mathrm{Cl}^{-}$channels by application of NPPB and found that NPPB enhanced swelling of ESCC cells during hypotonic shock. Furthermore, NPPB drastically slowed the decrease in cell volume following cell swelling during hypotonic shock. As a result, ESCC cells treated with NPPB were forced to maintain an extremely large cell volume for a long time, and most ESCC cells finally died. Our findings clearly demonstrated that inhibition of $\mathrm{Cl}^{-}$ channels during hypotonic shock enhances the cell swelling and cytocidal effects on ESCC cells.

Throughout these experiments, we found differences in the cell volume changes and the cytocidal effects induced by hypotonic shock among the three ESCC cell lines examined. As possible mechanisms, the strength of the cytoskeleton or the membrane, or the expression of the $\mathrm{Cl}^{-}$channels may differ among these ESCC cell lines. Further, overexpression of several types of aquaporins (AQP), transmembrane water channel proteins which play an important role in transcellular water movement, has been reported in different types of human cancer (24-27). cAMP has been reported to up-regulate AQP5 expression in lung epithelial cells, hence increasing water permeability (28). Therefore, cell swelling and disruption induced by hypotonic shock may be caused by the expression levels of certain types of ion channels or transporters in cancer cells. 
In conclusion, we demonstrated the cytocidal effects of hypotonic shock induced by distilled water on ESCC cells, and clearly support the efficacy of pleural lavage with distilled water during surgery for ESCC.

\section{Acknowledgements}

This work was supported by Grant-in-Aid for Young Scientists (B) (22791295) and Grant-in-Aid for Scientific Research (C) (22591464) from Japan Society for the Promotion of Science, and Research Grant Awards from Kyoto Preventive Medical Center to Dr Atsushi Shiozaki.

\section{References}

1. Doki Y, Kabuto T, Ishikawa O, et al: Does pleural lavage cytology before thoracic closure predict both patient's prognosis and site of cancer recurrence after resection of esophageal cancer? Surgery 130: 792-797, 2001.

2. Jiao X, Zhang M, Wen Z and Krasna MJ: Pleural lavage cytology in esophageal cancer without pleural effusions: clinicopathologic analysis. Eur J Cardiothorac Surg 17: 575-579, 2000.

3. Natsugoe S, Shimada M, Nakashima S, et al: Intraoperative pleural lavage in esophageal carcinoma. Ann Surg Oncol 6: 305-307, 1999.

4. Natsugoe S, Tokuda K, Matsumoto M, et al: Molecular detection of free cancer cells in pleural lavage fluid from esophageal cancer patients. Int J Mol Med 12: 771-775, 2003.

5. Caplanusi A, Kim KJ, Lariviere E, Van Driessche W and Jans D: Swelling-activated $\mathrm{K}^{+}$efflux and regulatory volume decrease efficiency in human bronchial epithelial cells. J Membr Biol 214: 33-41, 2006.

6. Miyazaki H, Shiozaki A, Niisato N and Marunaka Y: Physiological significance of hypotonicity-induced regulatory volume decrease: reduction in intracellular Cl-concentration acting as an intracellular signaling. Am J Physiol Renal Physiol 292: F1411-F1417, 2007.

7. Nishihira T, Hashimoto Y, Katayama M, Mori S and Kuroki T: Molecular and cellular features of esophageal cancer cells. J Cancer Res Clin Oncol 119: 441-449, 1993.

8. Shimada Y, Imamura M, Wagata T, Yamaguchi $\mathrm{N}$ and Tobe T: Characterization of 21 newly established esophageal cancer cel lines. Cancer 69: 277-284, 1992.

9. Shiozaki A, Miyazaki H, Niisato N, et al: Furosemide, a blocker of $\mathrm{Na}^{+} / \mathrm{K}^{+} / 2 \mathrm{Cl}^{-}$cotransporter, diminishes proliferation of poorly differentiated human gastric cancer cells by affecting G0/G1 state. J Physiol Sci 56: 401-406, 2006.

10. Kamangar F, Dores GM and Anderson WF: Patterns of cancer incidence, mortality, and prevalence across five continents: defining priorities to reduce cancer disparities in different geographic regions of the world. J Clin Oncol 24: 2137-2150, 2006.

11. Buhr J, Berghauser KH, Gonner S, Kelm C, Burkhardt EA and Padberg WM: The prognostic significance of tumor cell detection in intraoperative pleural lavage and lung tissue cultures for patients with lung cancer. J Thorac Cardiovasc Surg 113: 683-690, 1997
12. Higashiyama M, Doi O, Kodama $\mathrm{K}$, et al: Pleural lavage cytology immediately after thoracotomy and before closure of the thoracic cavity for lung cancer without pleural effusion and dissemination: clinicopathologic and prognostic analysis. Ann Surg Oncol 4: 409-415, 1997.

13. Okada M, Tsubota N, Yoshimura M, Miyamoto Y and Maniwa Y: Role of pleural lavage cytology before resection for primary lung carcinoma. Ann Surg 229: 579-584, 1999.

14. Okumura M, Ohshima S, Kotake Y, Morino H, Kikui M and Yasumitsu T: Intraoperative pleural lavage cytology in lung cancer patients. Ann Thorac Surg 51: 599-604, 1991.

15. Huguet EL and Keeling NJ: Distilled water peritoneal lavage after colorectal cancer surgery. Dis Colon Rectum 47: 2114-2119, 2004.

16. Levin DR and Moskovitz B: Distilled water versus chemotherapeutic agents for transitional bladder carcinoma. Eur Urol 12: 418-421, 1986.

17. Lin $\mathrm{CH}$, Hsieh HF, Yu JC, Chen TW, Yu CY and Hsieh CB: Peritoneal lavage with distilled water during liver resection in patients with spontaneously ruptured hepatocellular carcinomas. J Surg Oncol 94: 255-256, 2006.

18. Hua SZ, Gottlieb PA, Heo J and Sachs F: A mechanosensitive ion channel regulating cell volume. Am J Physiol Cell Physiol 298: C1424-C1430, 2010.

19. Lock H and Valverde MA: Contribution of the IsK (MinK) potassium channel subunit to regulatory volume decrease in murine tracheal epithelial cells. J Biol Chem 275: 34849-34852, 2000.

20. van Tol BL, Missan S, Crack J, et al: Contribution of KCNQ1 to the regulatory volume decrease in the human mammary epithelial cell line MCF-7. Am J Physiol Cell Physiol 293: C1010-C1019, 2007.

21. Wang J, Morishima S and Okada Y: IK channels are involved in the regulatory volume decrease in human epithelial cells. Am J Physiol Cell Physiol 284: C77-C84, 2003.

22. Boudreault F and Grygorczyk R: Cell swelling-induced ATP release and gadolinium-sensitive channels. Am J Physiol Cell Physiol 282: C219-C226, 2002.

23. Brundell SM, Tucker K, Chatterton B and Hewett PJ: The effect of lavage on intraabdominal cell burden. Surg Endosc 16: 1064-1067, 2002.

24. Hoque MO, Soria JC, Woo J, et al: Aquaporin 1 is overexpressed in lung cancer and stimulates NIH-3T3 cell proliferation and anchorage-independent growth. Am J Pathol 168: 1345-1353, 2006.

25. Kang SK, Chae YK, Woo J, et al: Role of human aquaporin 5 in colorectal carcinogenesis. Am J Pathol 173: 518-525, 2008.

26. Woo J, Lee J, Chae YK, et al: Overexpression of AQP5, a putative oncogene, promotes cell growth and transformation. Cancer Lett 264: 54-62, 2008.

27. Zhang Z, Chen Z, Song Y, Zhang P, Hu J and Bai C: Expression of aquaporin 5 increases proliferation and metastasis potential of lung cancer. J Pathol 221: 210-220, 2010.

28. Yang F, Kawedia JD and Menon AG: Cyclic AMP regulates aquaporin 5 expression at both transcriptional and posttranscriptional levels through a protein kinase A pathway. J Biol Chem 278: 32173-32180, 2003. 